\title{
The Nature of Arginine Auxotrophy in Cutaneous Populations of Staphylococci
}

\author{
By M. EMMETT* AND W. E. KLOOS \\ Department of Genetics, North Carolina State University, \\ Raleigh, North Carolina 27650, U.S.A.
}

(Received 1 June 1978)

\begin{abstract}
L-Arginine was required for growth by a high percentage of strains of Staphylococcus species that were niche-specific and/or host-specific, but was usually not required for growth by species showing a wide host range. Growth stimulation patterns with arginine intermediates indicated that most of the auxotrophic strains had blocks in an early step(s) in arginine biosynthesis. These strains were designated phenotypically as $\operatorname{Arg}(\mathrm{CHG})$ according to the Salmonella typhimurium classification scheme. Staphylococcus simulans strains appeared to be either ArgA or ArgI. The ArgI strains of S. simulans and S. capitis had moderate to high ornithine carbamoyltransferase (EC 2.1.3.3) activities and therefore could not be designated as $\operatorname{argI}$ mutants. ArgI strains in other species had no or very low ornithine carbamoyltransferase activities. All of the natural Staphylococcus auxotrophs tested grew in the presence of L-citrulline and had moderate to high argininosuccinase (EC 4.3.2.1) activities. Arginine auxotrophs of species with a wide host range were often capable of reverting to arginine-independent or complete prototrophic growth, whereas auxotrophs of species that tended to be niche-specific and/or host-specific were incapable of reversion to arginine-independence, even in the presence of various mutagens. A relationship between the nature of arginine auxotrophy and habitat is suggested.
\end{abstract}

\section{INTRODUCTION}

Populations of staphylococci isolated from the skin of man and other mammals can be divided into two major groups on the basis of whether or not they require amino acids for growth (Emmett \& Kloos, 1975; unpublished results). Staphylococci requiring amino acids for growth demonstrate species-specific or species group-specific patterns. In the majority of species studied to date (e.g. Staphylococcus aureus, S. intermedius, S. simulans, S. haemolyticus, $S$. warneri, $S$. hominis, S. epidermidis and $S$. capitis) the most commonly essential amino acids are arginine, valine and proline. Amino acids are rarely required by such species as $S$. xylosus and $S$. sciuri, but any such requirement is usually for one of the above amino acids.

Arginine and valine are found in relatively high concentrations $(135 \cdot 8 \pm 39 \cdot 2$ and $29 \cdot 6 \pm$ $7.5 \mu \mathrm{g} \mathrm{ml}^{-1}$, respectively) in normal human sweat that bathes the skin surface (Hier et al., 1946; Farrior \& Kloos, 1976). In addition to arginine, citrulline and presumably ornithine (intermediates of arginine biosynthesis) are present on the human skin surface (Rothman \& Sullivan, 1949).

In another mammalian host-adapted species, Neisseria gonorrhoeae, arginine, proline, and valine are also among the most commonly required amino acids (Catlin, 1976; Young et al., 1977).

* Present address: Eleanor Roosevelt Institute for Cancer Research, Inc., 4200 East Ninth Avenue, Denver, Colorado 80262, U.S.A. 

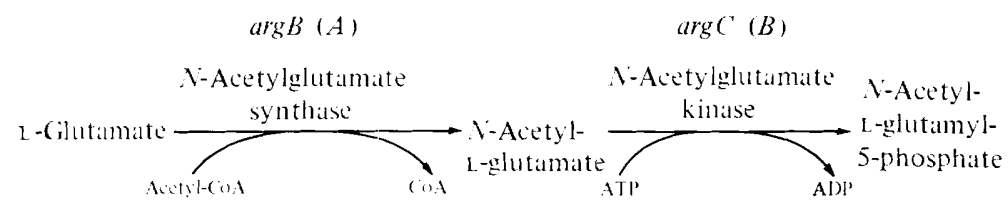

$\arg G(D)$

Acetylornithine

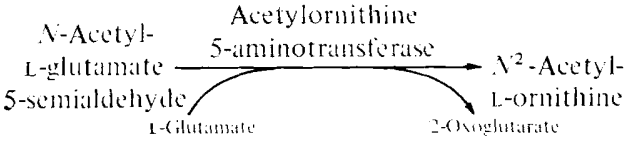

$\operatorname{argti}(G)$

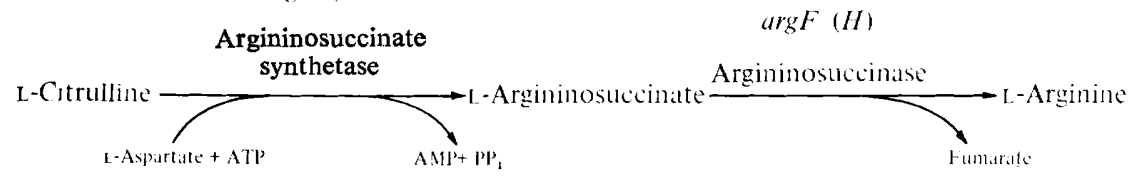

Fig. 1. The arginine biosynthetic pathway of Salmonella typhimurium and Escherichia coli (Sanderson, 1972; Vogel \& Vogel, 1974). Escherichia coli locus designations are shown in parentheses.

In the study reported here, we have explored the nature of the arginine requirement (auxotrophy) in various populations of staphylococci isolated from mammalian skin. One of the purposes of this investigation was to identify the blocks in L-arginine biosynthesis responsible for natural auxotrophy in staphylococci. In the biosynthetic pathway, L-glutamate is ultimately converted to L-arginine. Escherichia coli (Vogel et al., 1963; Vogel \& Vogel, 1974), Salmonella typhimurium (Demerec et al., 1960), Proteus mirabilis (Prozesky, 1967) and Bacillus subtilis (Vogel \& Vogel, 1963a) utilize the pathway shown in Fig. 1. Our study was also designed to determine whether or not arginine auxotrophy in staphylococci could be induced to revert to prototrophy by various mutagens, in order to gain insight into the genetic nature of the requirement.

\section{METHODS}

Bacterial strains. The Staphylococcus strains used in this investigation have been classified previously and were isolated from an average of 12 sites on the healthy skin of two subgroups of people, consisting of 20 individuals per subgroup, living in different regions of the U.S.A. (Kloos \& Schleifer, 1975; Schleifer \& Kloos, 1975 ) and from the skin of various domestic and wild animals from different areas (Kloos et al., 1976a,b). The skin flora from these subgroups and a third subgroup from London (Kloos \& Noble, unpublished) did not differ significantly, as was the case for animal species from different regions. Thus, we believe that these strains are representative of the general population of cutaneous staphylococci. The 1059 strains studied are too numerous to list individually; however, the numbers of strains studied of each species and their sources are summarized in Table 1.

Salmonella typhimurium reference arginine auxotrophs $\arg A 55, \arg B 51, \operatorname{argC113}, \operatorname{argE72}, \arg F 87$ and $\operatorname{argH} 93$, derived from strain LT2, were obtained from Dr K. E. Sanderson, University of Calgary, Calgary, Alberta, Canada. Salmonella typhimurium arg1537, derived from strain LT7, was obtained from Dr J. Roth, University of California, Berkeley, California, U.S.A.

Media and cultural conditions. Growth stimulation of staphylococci by intermediates of the arginine biosynthetic pathway and reversion properties of arginine auxotrophs were tested on a defined agar medium described previously (Emmett \& Kloos, 1975), but with the omission of L-arginine. The pH of the medium was adjusted to $7 \cdot 0$ by adding $1 \mathrm{M}-\mathrm{NaOH}$ before sterilization. For assays of arginine biosynthetic enzymes, staphylococci were grown in a defined broth medium that differed from the above medium by the omission of Noble agar and the addition of $100 \mu \mathrm{g} \mathrm{L}$-citrulline $\mathrm{ml}^{-1}$.

Salmonella typhimurium $\arg A, \arg B, \arg C, \arg H$ and $\arg I$ auxotrophs were grown in medium $E$ broth (Vogel \& Bonner, 1956) supplemented with $100 \mu \mathrm{g} \mathrm{L}$-citrulline $\mathrm{ml}^{-1}$ for assays of arginine biosynthetic enzymes. They 


\title{
Table 1. Summary of Staphylococcus strains and species
}

\begin{tabular}{cl}
$\begin{array}{c}\text { No. of } \\
\text { strains }\end{array}$ & \multicolumn{1}{c}{ Species } \\
45 & S. aureus \\
8 & S. intermedius \\
160 & S. xylosus \\
& \\
& \\
65 & S. cohnii (includes 4 \\
& tentative subspecies) \\
74 & S. saprophyticus \\
30 & S. sciuri subsp. sciuri
\end{tabular}

\author{
Cutaneous source*
}

Man

Man (5) †; $\operatorname{dog}(2)$; Squirrel monkey, Saimiri sciurea (1)

Man (98); sheep (22); horse (11); cattle (8); Southern flying squirrel, Glaucomys volans (7); Eastern grey squirrel, Sciurus carolinensis (6); $\operatorname{dog}(6)$; pig (1); opossum, Didelphis marsupialis (virginiana) (1)

Man (40); Squirrel monkey (14); opossum (10); pig (1)

Man

Eastern grey squirrel (14); opossum (9); man (5) $\dagger$; Southern flying squirrel (3); raccoon, Procyon lotor (1); dog (1); sheep (1)

\begin{tabular}{|c|c|c|}
\hline 14 & S. sciuri subsp. lentus & Goat (9); sheep (5) \\
\hline 21 & S. simulans & Man \\
\hline 116 & S. haemolyticus & $\operatorname{Man}(109)$; pig (5) $\dagger$; cattle $(2) \dagger$ \\
\hline 41 & S. warneri & Man \\
\hline 201 & S. hominis & Man \\
\hline 186 & S. epidermidis & Man \\
\hline 44 & S. capitis & Man \\
\hline 42 & Staphylococcus sp. 3 & $\begin{array}{l}\text { Opossum (15); Eastern grey squirrel (14); } \\
\text { Southern flying squirrel (5); raccoon (5); pig } \\
\text { (2); sheep (1) }\end{array}$ \\
\hline 7 & Staphylococcus sp. 4 & Opossum \\
\hline 5 & Staphylococcus sp. 5 & Squirrel monkey \\
\hline
\end{tabular}

* The number of strains isolated from each mammalian host species is shown in parentheses.

$\dagger$ Strains suspected as being transient contaminants which originated by contact with natural hosts.

were grown on medium $\mathrm{E}$ agar plates for growth stimulation and reversion analyses. The $\arg F 87$ auxotroph was grown on medium $\mathrm{E}$ agar and broth as described above, but with $2 \mu \mathrm{g} \mathrm{L}$-arginine $\mathrm{ml}^{-1}$ instead of $\mathrm{L}-$ citrulline.

Stock Staphylococcus spp. and Salmonella typhimurium cultures were maintained on P agar (Naylor \& Burgi, 1956) slopes at $4^{\circ} \mathrm{C}$. Staphylococci isolated from skin were transferred (subcultured) one to four times on $\mathbf{P}$ agar between the time of their original isolation and use in the nutritional studies reported here. This limited amount of subculturing did not affect the original amino acid requirements or the arginine biosynthetic enzyme activities of 10 randomly selected control strains.

Growth stimulation by arginine intermediates. Several crystals of L-glutamic acid, $N$-acetyl-L-glutamic acid, $N^{2}$-acetyl-L-ornithine, L-ornithine, L-citrulline and L-arginine were placed on separate defined agar plates, which had been spread on the surface with approximately $10^{7}$ colony-forming units (c.f.u.) of either Staphylococcus spp. or Salmonella typhimurium auxotrophs. Cultures were incubated at $34{ }^{\circ} \mathrm{C}$ for $48 \mathrm{~h}$ and then examined for evidence of growth stimulation around the area of the bacterial lawn where crystals were absorbed.

Cell extract preparation. Cell extracts of Staphylococcus spp. and Salmonella typhimurium for enzyme assays were prepared from $200 \mathrm{ml}$ cultures (initial density approximately $5 \times 10^{2}$ c.f.u. $\mathrm{ml}^{-1}$ ) grown in $500 \mathrm{ml}$ Erlenmeyer flasks for $24 \mathrm{~h}$ at $37^{\circ} \mathrm{C}$ with shaking at $250 \mathrm{rev} . \mathrm{min}^{-1}$ in a Controlled Environment Incubator Shaker (New Brunswick Scientific Co.). Cells were harvested by centrifuging and washed in $10 \mathrm{ml} 0.1 \mathrm{M}-$ potassium phosphate buffer, $\mathrm{pH} 7 \cdot 0$. Washed cell pellets were resuspended in $0 \cdot 1 \mathrm{M}$-potassium phosphate buffer, pH 7.0, containing 2 mm-glutathione (reduced). Staphylococcus spp. cell extracts were prepared according to the procedures described previously (Proctor \& Kloos, 1973). Salmonella typhimurium was disrupted by two passages through a French press $(100 \mathrm{MPa})$. The protein concentration of cell extracts was determined by the method of Lowry et al. (1951). 


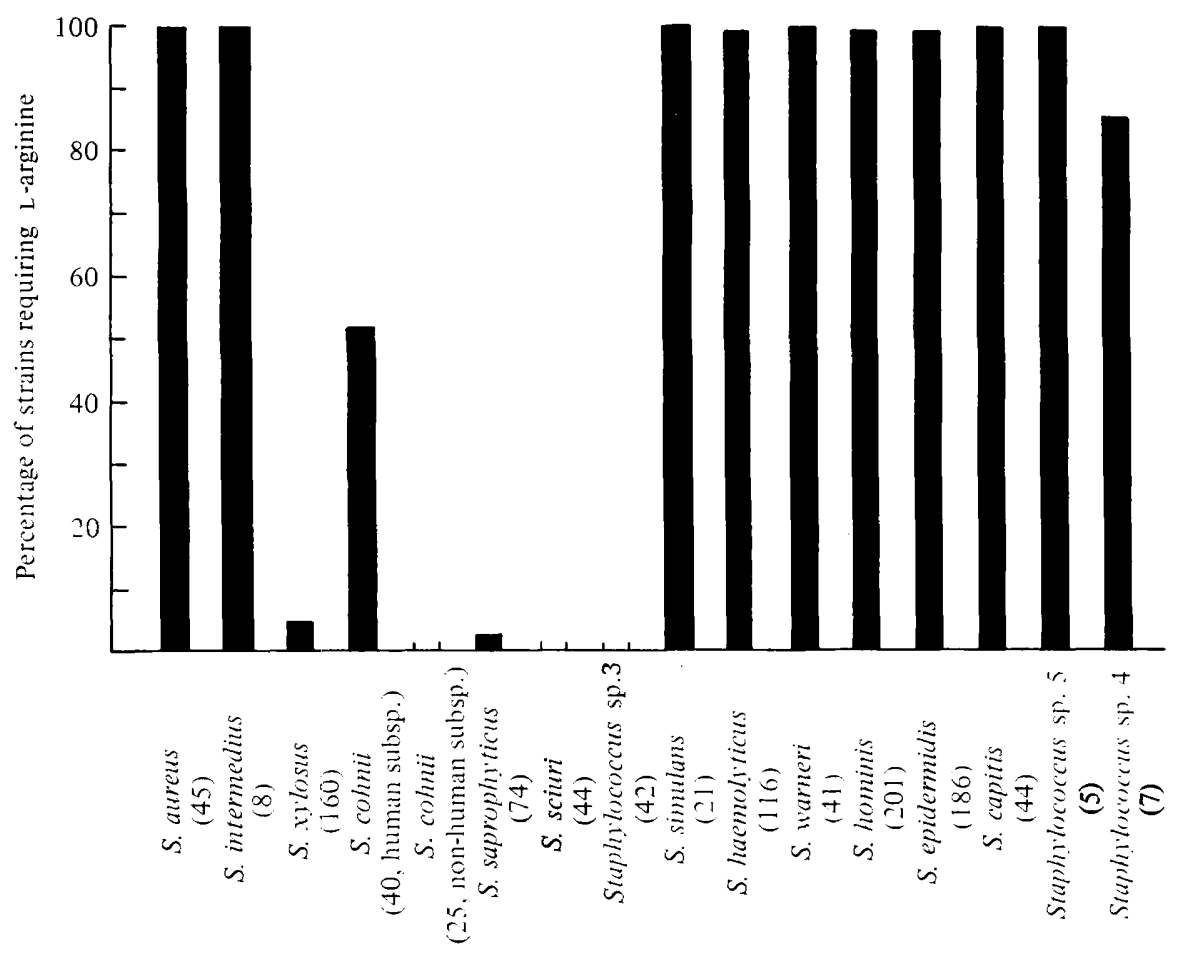

Fig. 2. Percentages of Staphylococcus strains requiring arginine for growth.

Enzyme assays. Ornithine carbamoyltransferase (EC 2.1.3.3) activity was assayed by a modification of the procedure of Jones et al. (1955) as described by Theil et al. (1969). The assay incubation period was 20 min for Salmonella typhimurium extracts and 10 or $60 \mathrm{~min}$ for Staphylococcus spp. extracts.

Argininosuccinase (EC 4.3.2.1) was assayed by a modification of the procedure outlined by Theil et al. (1969) in which $10 \mu \mathrm{mol} \mathrm{K}_{2} \mathrm{HPO}_{4}$, $\mathrm{pH} 9 \cdot 5$, was used in place of the potassium phosphate buffer, $\mathrm{pH} 7 \cdot 5$. Enzyme assay mixtures were incubated for $60 \mathrm{~min}$ with Salmonella typhimurium extracts and $15 \mathrm{~min}$ with Staphylococeus spp. extracts.

Mutagen-induced reversion of arginine auxotrophy to prototrophy. Single drops $(0.05 \mathrm{ml})$ of aqueous solutions of $1 \mathrm{mg} N$-methyl- $N^{\prime}$-nitro- $N$-nitrosoguanidine (NTG) $\mathrm{ml}^{-1}, 1 \cdot 2 \mathrm{~g}$ ethyl methanesulphonate (EMS) $\mathrm{ml}^{-1}$, $1 \mathrm{mg}$ diethyl sulphate (DES) $\mathrm{ml}^{-1}, 1 \mathrm{mg}$ Institute for Cancer Research (ICR)-170G $\mathrm{ml}^{-1}$ and $1 \mathrm{mg} \mathrm{ICR}^{-}$ $191 \mathrm{E} \mathrm{ml} l^{-1}$ were placed on separate defined agar plates, freshly inoculated on the surface with approximately $10^{7}$ c.f.u. of either selected Staphylococcus arginine auxotrophs, control Salmonella typhimurium arginine or cysteine auxotrophs with previously characterized mutations (K. E. Sanderson, personal communication), or Micrococcus cysteine auxotrophs. One control plate, containing defined agar without mutagens, was used to test the spontaneous reversion properties of each auxotrophic strain. Cultures were incubated at $34{ }^{\circ} \mathrm{C}$ for $48 \mathrm{~h}$ and then examined for the presence of prototrophic (revertant) colonies around the area of the bacterial lawn where the mutagen was absorbed. The resulting arginine-independent colonies were tested for stability of growth properties by serial propagation on defined agar plates.

Chemicals. EMS was obtained from Eastman Organic Chemicals, NTG was from K \& K Laboratories, Plainview, N.Y., U.S.A., and lysostaphin was from Schwartz/Mann, Orangeburg, N.Y., U.S.A. ICR-170G and ICR-191E were kindly supplied by Dr Hugh J. Creech, Institute for Cancer Research, Philadelphia, Pa., U.S.A.

\section{RESULTS}

\section{Arginine auxotrophy in cutaneous populations of staphylococci}

For each Staphylococcus species studied, the percentage of strains requiring L-arginine for growth is shown in Fig. 2. In coagulase-positive species and the coagulase-negative 
$S$. simulans and $S$. epidermidis species group, composed of $S$. epidermidis sensu stricto, S. hominis, S. haemolyticus, S. warneri and S. capitis, 99 to $100 \%$ of the strains required L-arginine. Of the strains of $S$. cohnii subspecies isolated from human skin, $52.5 \%$ required L-arginine whereas subspecies of $S$. cohnii isolated from various wild and domestic animals did not require this amino acid. The reason for the marked difference in requirement is unclear, but it could conceivably be related to differences in the availability of L-arginine in human and certain other mammalian cutaneous habitats. Other members of the $S$. saprophyticus species group and S. sciuri, including both of its recognized subspecies, were predominantly or entirely composed of strains that did not require L-arginine.

Slightly more than half of the strains of S. saprophyticus required L-proline and L-valine for growth (Emmett \& Kloos, 1975). Over 95\% of S. sciuri subsp. sciuri and Staphylococcus sp. 3 strains and $89 \%$ of $S$. xylosus strains were completely prototrophic and able to grow well on a modification of the defined medium (see Methods) containing $\left(\mathrm{NH}_{4}\right)_{2} \mathrm{SO}_{4}$ as a sole source of nitrogen.

\section{Growth stimulation by arginine intermediates}

The Salmonella typhimurium reference arginine auxotrophs showed the growth stimulation patterns that would be expected on the basis of their mutant classification, except that $\arg B 51$ was not stimulated by $N$-acetyl-L-glutamic acid. $\operatorname{ArgB51}$, blocked at the first step in the biosynthesis of arginine (Fig. 1), was stimulated by $N^{2}$-acetyl-L-ornithine, L-ornithine, $\mathrm{L}$-citrulline and L-arginine; $\operatorname{argC113}$, blocked at the second step, and $\arg H 93$, blocked at the third step, were also stimulated by these intermediates; $\arg A 55$, blocked at the fifth step, was stimulated by L-ornithine, L-citrulline and L-arginine; $\arg 1537$, blocked at the sixth step,

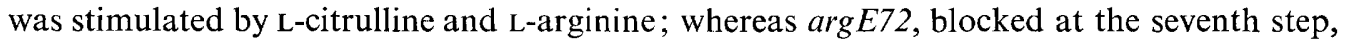
and $\arg F 87$, blocked at the eight step, were stimulated only by L-arginine.

Table 2 shows the results of testing Staphylococcus arginine auxotrophs for growth stimulation by various arginine intermediates. For most species, a high percentage of the strains were $\operatorname{Arg}(\mathrm{CHG})$, i.e. blocked early (step 4 and/or earlier) in the biosynthetic pathway leading to L-arginine. These auxotrophs may have single or multiple blocks in the early part of the pathway, the determination of which will require future assays for $N$-acetylglutamate synthase (EC 2.3.1.1), $\mathrm{N}$-acetylglutamate kinase (EC 2.7.2.8), $\mathrm{N}$-acetylglutamate-5-semialdehyde dehydrogenase (EC 1.2.1.38) and acetylornithine 5-aminotransferase(EC 2.6.1.11) activities. Cross-feeding of auxotrophs could not be demonstrated. Staphylococcus simulans was unique in that none of the 21 strains tested were phenotypically $\operatorname{Arg}(\mathrm{CHG})$; they were all ArgA or ArgI. These and similar auxotrophs found in other species may also have single or multiple blocks in the early part of the pathway, but our results show that they have, at least, a later block than those found in $\operatorname{Arg}(\mathrm{CHG})$ auxotrophs, since they were unable to grow on $N^{2}$-acetyl-L-ornithine and/or L-ornithine. Staphylococcus capitis was different in that most strains $(68 \%)$ were ArgA auxotrophs.

\section{Arginine biosynthetic enzyme assays}

Activities of ornithine carbamoyltransferase and argininosuccinase (enzymes catalysing the sixth and eighth steps in L-arginine biosynthesis, respectively) were assayed in reference Salmonella typhimurium and Staphylococcus arginine auxotrophs.

ArgI designated auxotrophs that are actually argI mutants should have insufficient ornithine carbamoyltransferase activity for growth on L-ornithine. The specific activities in reference Salmonella typhimurium $\arg B, \arg C, \arg H, \arg A$ and $\arg F$ mutants were between 0.84 and 12 units (mg protein) ${ }^{-1}$, whereas the $\arg I$ mutant specific activity was only 0.05 . The specific activities in representative Staphylococcus strains are shown in Table 3. Selected ArgI auxotrophs in the species $S$. intermedius, $S$. xylosus, $S$. warneri, $S$. hominis and $S$. epidermidis had very low or no ornithine carbamoyltransferase activity. This finding is consistent with their inability to growth on L-ornithine, in place of L-citrulline or L-arginine, 
Table 2. Growth stimulation of cutaneous Staphylococcus arginine auxotrophs by arginine intermediates

\begin{tabular}{|c|c|c|c|c|c|c|c|c|c|}
\hline \multirow[b]{2}{*}{ Species } & \multirow{2}{*}{$\begin{array}{l}\text { No. of } \\
\text { strains } \\
\text { tested }\end{array}$} & \multirow{2}{*}{$\begin{array}{c}\text { Auxo- } \\
\text { trophic } \\
\text { class } \dagger\end{array}$} & \multirow{2}{*}{$\begin{array}{l}\text { Percent- } \\
\text { age of } \\
\text { strains } \\
\text { in class }\end{array}$} & \multicolumn{6}{|c|}{ Arginine intermediates* } \\
\hline & & & & Glu & AcGlu & AcOrn & Orn & Cit & $\operatorname{Ar}$ \\
\hline S. aureus & 45 & $\begin{array}{l}\operatorname{Arg}(\mathrm{CHG}) \\
\operatorname{ArgA}\end{array}$ & $\begin{array}{l}78 \\
22\end{array}$ & $\overline{-}$ & $\begin{array}{l}- \\
-\end{array}$ & $\begin{array}{l}+ \\
-\end{array}$ & $\begin{array}{l}+ \\
+\end{array}$ & $\begin{array}{l}+ \\
+\end{array}$ & $\begin{array}{l}+ \\
+\end{array}$ \\
\hline S. intermedius & 8 & $\begin{array}{l}\operatorname{Arg}(\mathrm{CHG}) \\
\operatorname{ArgA} \\
\text { ArgI }\end{array}$ & $\begin{array}{l}50 \\
38 \\
12\end{array}$ & $\begin{array}{l}- \\
-\end{array}$ & $\begin{array}{l}- \\
-\end{array}$ & $\begin{array}{l}+ \\
-\end{array}$ & $\begin{array}{l}+ \\
+ \\
-\end{array}$ & $\begin{array}{l}+ \\
+ \\
+\end{array}$ & $\begin{array}{l}+ \\
+ \\
+\end{array}$ \\
\hline S. xylosus & 7 & $\begin{array}{l}\text { ArgI } \\
\text { Arg(CHG) } \\
\text { ArgA }\end{array}$ & $\begin{array}{l}57 \\
29 \\
14\end{array}$ & $\begin{array}{l}- \\
- \\
-\end{array}$ & $\begin{array}{l}- \\
- \\
-\end{array}$ & $\begin{array}{l}- \\
+ \\
-\end{array}$ & $\begin{array}{l}- \\
+ \\
+\end{array}$ & $\begin{array}{l}+ \\
+ \\
+\end{array}$ & $\begin{array}{l}+ \\
+ \\
+\end{array}$ \\
\hline $\begin{array}{l}\text { S. cohnii } \\
\text { (human subspecies) }\end{array}$ & 21 & $\begin{array}{l}\operatorname{Arg}(\mathrm{CHG}) \\
\operatorname{ArgA}\end{array}$ & $\begin{array}{r}95 \\
5\end{array}$ & $\begin{array}{l}- \\
-\end{array}$ & $\begin{array}{l}- \\
-\end{array}$ & $\begin{array}{l}+ \\
-\end{array}$ & $\begin{array}{l}+ \\
+\end{array}$ & $\begin{array}{l}+ \\
+\end{array}$ & $\begin{array}{l}+ \\
+\end{array}$ \\
\hline S. saprophyticus & 2 & $\begin{array}{l}\operatorname{Arg}(\mathrm{CHG}) \\
\operatorname{ArgB}\end{array}$ & $\begin{array}{l}50 \\
50\end{array}$ & $\begin{array}{l}- \\
-\end{array}$ & $\overline{+}$ & $\begin{array}{l}+ \\
+\end{array}$ & $\begin{array}{l}+ \\
+\end{array}$ & $\begin{array}{l}+ \\
+\end{array}$ & $\begin{array}{l}+ \\
+\end{array}$ \\
\hline S. simulans & 21 & $\begin{array}{l}\text { ArgI } \\
\text { ArgA }\end{array}$ & $\begin{array}{l}57 \\
43\end{array}$ & $\begin{array}{l}- \\
-\end{array}$ & $\begin{array}{l}- \\
-\end{array}$ & - & $\bar{t}$ & $\begin{array}{l}+ \\
+\end{array}$ & $\begin{array}{l}+ \\
+\end{array}$ \\
\hline S. haemolyticus & 115 & $\begin{array}{l}\operatorname{Arg}(\mathrm{CHG}) \\
\operatorname{ArgA}\end{array}$ & $\begin{array}{l}71 \\
29\end{array}$ & $\begin{array}{l}- \\
-\end{array}$ & $\begin{array}{l}- \\
-\end{array}$ & $\begin{array}{l}+ \\
-\end{array}$ & $\begin{array}{l}+ \\
+\end{array}$ & $\begin{array}{l}+ \\
+\end{array}$ & $\begin{array}{l}+ \\
+\end{array}$ \\
\hline S. warneri & 41 & $\begin{array}{l}\operatorname{Arg}(\mathrm{CHG}) \\
\text { ArgA } \\
\text { ArgI }\end{array}$ & $\begin{array}{r}71 \\
24 \\
5\end{array}$ & $\begin{array}{l}- \\
- \\
-\end{array}$ & $\begin{array}{l}- \\
- \\
-\end{array}$ & $\begin{array}{l}+ \\
-\end{array}$ & $\begin{array}{l}+ \\
+ \\
-\end{array}$ & $\begin{array}{l}+ \\
+ \\
+\end{array}$ & $\begin{array}{l}+ \\
+ \\
+\end{array}$ \\
\hline S. hominis & 200 & $\begin{array}{l}\operatorname{Arg}(\mathrm{CHG}) \\
\text { ArgA } \\
\text { ArgI }\end{array}$ & $\begin{array}{r}94 \\
6 \\
<1\end{array}$ & $\begin{array}{l}- \\
- \\
-\end{array}$ & $\begin{array}{l}- \\
-\end{array}$ & $\begin{array}{l}+ \\
-\end{array}$ & $\begin{array}{l}+ \\
+ \\
-\end{array}$ & $\begin{array}{l}+ \\
+ \\
+\end{array}$ & $\begin{array}{l}+ \\
+ \\
+\end{array}$ \\
\hline S. epidermidis & 185 & $\begin{array}{l}\operatorname{Arg}(\mathrm{CHG}) \\
\text { ArgA } \\
\text { ArgI }\end{array}$ & $\begin{array}{r}81 \\
14 \\
5\end{array}$ & $\begin{array}{l}- \\
- \\
-\end{array}$ & $\begin{array}{l}- \\
- \\
-\end{array}$ & $\begin{array}{l} \pm \\
-\end{array}$ & $\begin{array}{l}+ \\
+ \\
-\end{array}$ & $\begin{array}{l}+ \\
+ \\
+\end{array}$ & $\begin{array}{l}+ \\
+ \\
+\end{array}$ \\
\hline S. capitis & 44 & $\begin{array}{l}\operatorname{ArgA} \\
\operatorname{Arg}(\mathrm{CHG}) \\
\operatorname{ArgI}\end{array}$ & $\begin{array}{r}68 \\
30 \\
2\end{array}$ & $\begin{array}{l}- \\
- \\
-\end{array}$ & $\begin{array}{l}- \\
-\end{array}$ & $\begin{array}{l}- \\
+\end{array}$ & $\begin{array}{l}+ \\
+ \\
-\end{array}$ & $\begin{array}{l}+ \\
+ \\
+\end{array}$ & $\begin{array}{l}+ \\
+ \\
+\end{array}$ \\
\hline Staphylococcus sp. 5 & 5 & $\begin{array}{l}\operatorname{Arg}(\mathrm{CHG}) \\
\operatorname{ArgA}\end{array}$ & $\begin{array}{l}80 \\
20\end{array}$ & $\overline{-}$ & $\overline{-}$ & $\stackrel{+}{-}$ & $\begin{array}{l}+ \\
+\end{array}$ & $\begin{array}{l}+ \\
+\end{array}$ & $\begin{array}{l}+ \\
+\end{array}$ \\
\hline Staphylococcus sp. 4 & 6 & $\operatorname{Arg}(\mathrm{CHG})$ & 100 & - & - & + & + & + & + \\
\hline
\end{tabular}

+, Growth stimulation; -, no stimulation.

* Glu, L-glutamic acid; AcGlu, $N$-acetyl-L-glutamic acid; AcOrn, $N^{2}$-acetyl-L-ornithine; Orn, L-ornithine; Cit, L-citrulline; Arg, L-arginine.

$\uparrow$ Phenotypic symbols are according to the scheme used in Salmonella typhimurium (Sanderson, 1972). Parentheses around symbols indicate that the exact block in biosynthesis is not known. Furthermore, it is not certain that $\operatorname{Arg}(\mathrm{CHG})$ auxotrophs are not also blocked in the first step and therefore lack $\arg B$ gene function or that ArgA and ArgI mutants are blocked in only one step.

and suggests that they are probably argI mutants. We were surprised to find, however, that ArgI auxotrophs of $S$. simulans and $S$. capitis had high ornithine carbamoyltransferase activities. The failure of these auxotrophs to grow on L-ornithine may be related to a lack of other enzyme activities (e.g. a specific permease) or regulatory functions. Obviously, we do not consider that $S$. simulans or S. capitis ArgI designated auxotrophs are argI mutants.

All of the natural Staphylococcus arginine auxotrophs grew rapidly in the presence of L-citrulline in place of L-arginine. They would therefore be expected to possess sufficient argininosuccinase activity to convert L-argininosuccinate, derived from L-citrulline, to L-arginine to satisfy growth requirements. Our results indicate that this was the case. Specific activities ranged from $19 \cdot 1$ to $77 \cdot 1$ units (mg protein) ${ }^{-1}$, depending upon the particular 
Table 3. Specific activity of ornithine carbamoyltransferase in cutaneous Staphylococcus arginine auxotrophs

\begin{tabular}{|c|c|c|c|}
\hline Species & Strain & $\begin{array}{c}\text { Auxotrophic } \\
\text { class* }\end{array}$ & $\begin{array}{c}\text { Specific } \\
\text { activity } \dagger\end{array}$ \\
\hline S. aureus & $\begin{array}{l}\text { HK } 41 \\
\text { AW } 100\end{array}$ & $\begin{array}{l}\text { ArgA } \\
\text { ArgA }\end{array}$ & $\begin{array}{l}13 \cdot 9 \\
87 \cdot 5\end{array}$ \\
\hline S. intermedius & $\begin{array}{l}\text { DW } 258 \\
\text { RK } 12 \\
\text { SK 2 } \\
\text { HM } 13 \\
\text { HK 91 }\end{array}$ & $\begin{array}{l}\operatorname{Arg}(\mathrm{CHG}) \\
\text { ArgA } \\
\text { ArgA } \\
\text { ArgA } \\
\text { ArgI }\end{array}$ & $\begin{array}{r}71 \cdot 8 \\
41 \cdot 6 \\
73 \cdot 1 \\
55 \cdot 3 \\
0 \cdot 1\end{array}$ \\
\hline S. xylosus & $\begin{array}{l}\text { CK } 15 \\
\text { RM } 383 \\
\text { EC } 323 \\
\text { EC } 325\end{array}$ & $\begin{array}{l}\operatorname{Arg}(\mathrm{CHG}) \\
\text { Argl } \\
\text { ArgI } \\
\text { ArgI }\end{array}$ & $\begin{array}{r}629 \\
2 \cdot 4 \\
0 \cdot 5 \\
0 \cdot 0\end{array}$ \\
\hline S. simulans & $\begin{array}{l}\text { SM } 128 \\
\text { LH } 303 \\
\text { SM } 81 \\
\text { ATCC } 27849 \\
\text { KL 299 } \\
\text { AW 232 } \\
\text { JHB 21 } \\
\text { MAW 222 }\end{array}$ & $\begin{array}{l}\text { ArgA } \\
\text { ArgA } \\
\text { ArgA } \\
\text { ArgA } \\
\text { ArgI } \\
\text { ArgI } \\
\text { ArgI } \\
\text { ArgI }\end{array}$ & $\begin{array}{l}389 \\
733 \\
471 \\
286 \\
236 \\
231 \\
589 \\
68 \cdot 2\end{array}$ \\
\hline S. epidermidis & $\begin{array}{l}\text { RM } 351 \\
\text { AW } 76 \\
\text { RM } 172 \\
\text { RM } 233 \\
\text { PM } 325 \\
\text { WK } 5\end{array}$ & $\begin{array}{l}\text { Arg }(\mathrm{CHG}) \\
\text { ArgI } \\
\text { ArgI } \\
\text { ArgI } \\
\text { ArgI } \\
\text { ArgI }\end{array}$ & $\begin{array}{c}186 \\
0.6 \\
0.0 \\
0.0 \\
0.6 \\
0.8\end{array}$ \\
\hline S. warneri & $\begin{array}{l}\text { JL } 202 \\
\text { SE } 3\end{array}$ & $\begin{array}{l}\text { ArgI } \\
\text { ArgI }\end{array}$ & $\begin{array}{l}0 \cdot 4 \\
0 \cdot 8\end{array}$ \\
\hline S. hominis & JL 326 & ArgI & $1 \cdot 7$ \\
\hline S. capitis & HM 11 & $\operatorname{ArgI} *$ & 119 \\
\hline
\end{tabular}

* Phenotypic symbols are according to the scheme used in Salmonella typhimurium (Sanderson, 1972). Auxotrophic class designations were determined on the basis of growth stimulation patterns by arginine intermediates. Parentheses around symbols indicate that the exact block in biosynthesis is not known.

$\dagger$ Specific activity is expressed as units (mg protein) ${ }^{-1}$.

* ArgI auxotrophic class designation is not consistent with specific activity results.

strain. Attempts to assay other arginine biosynthetic enzymes in staphylococci were unsuccessful, although activities could be demonstrated in specific reference Salmonella typhimurium strains.

\section{Reversion properties of arginine auxotrophs}

Salmonella typhimurium reference mutants $\operatorname{argC113}$, $\operatorname{argF87}$ and $\operatorname{argH93,~known~to~}$ contain deletions or multisite mutations within their affected arg gene (K. E. Sanderson, personal communication), failed to produce prototrophic revertants with any of the muta-

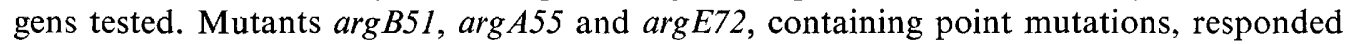
to one or more of the alkylating agents NTG, EMS and DES.

The reversion responses of various cutaneous Staphylococcus arginine auxotrophs are indicated in Table 4. None of the $S$. aureus, $S$. intermedius, $S$. simulans, $S$. warneri, $S$. capitis or Staphylococcus sp. 4 arginine auxotrophs tested demonstrated reversion to arginine-independence, either spontaneously or with mutagen pressure. These species, nevertheless, produced pigment and/or morphologically recognizable mutants when treated with the alkylating agents, indicating mutagen uptake. Species included in the S. saprophyticus species group contained a moderate to high percentage of arginine auxotrophs capable of reverting to arginine-independent or complete prototrophic growth. 
Table 4. Reversion of cutaneous Staphylococcus arginine auxotrophs to arginine-independence

\begin{tabular}{|c|c|c|c|}
\hline Species & $\begin{array}{c}\text { No. of } \\
\text { strains tested }\end{array}$ & $\begin{array}{l}\text { Percentage } \\
\text { of strains } \\
\text { showing } \\
\text { spontaneous } \\
\text { reversion }\end{array}$ & $\begin{array}{l}\text { Percentage } \\
\text { of strains } \\
\text { showing re- } \\
\text { version in } \\
\text { response to } \\
\text { alkylating } \\
\text { mutagen* }\end{array}$ \\
\hline S. aureus & 13 & 0 & 0 \\
\hline S. intermedius & 8 & 0 & 0 \\
\hline S. xylosus & 7 & 71 & 71 \\
\hline S. cohnii & 14 & 29 & 36 \\
\hline S. saprophyticus & 2 & 50 & 50 \\
\hline S. simulans & 13 & 0 & 0 \\
\hline S. haemolyticus & 30 & 13 & 23 \\
\hline S. warneri & 17 & 0 & 0 \\
\hline S. hominis & 25 & 8 & 12 \\
\hline S. epidermidis & 34 & 41 & 47 \\
\hline S. capitis & 14 & 0 & 0 \\
\hline Staphylococcus sp. 5 & 5 & 40 & 40 \\
\hline Staphylococcus sp. 4 & 6 & 0 & 0 \\
\hline
\end{tabular}

* Mutagens included $N$-methyl- $N^{\prime}$-nitro- $N$-nitrosoguanidine, ethyl methanesulphonate and diethyl sulphate.

This property remained stable over the three transfers tested on the defined agar medium lacking L-arginine. The major human species found in the $S$. epidermidis species group, including $S$. epidermidis, $S$. hominis and $S$. haemolyticus, and the major Squirrel monkey species, Staphylococcus sp. 5, also found in this group, contained a low to moderate percentage of arginine auxotrophs capable of reverting to arginine-independence. None of the arginine auxotrophs were induced to revert in the presence of the ICR mutagens suggesting that they were not frame-shift mutants. The ICR mutagen preparations were active as they induced reversion to prototrophy in several reference Micrococcus cysteine auxotrophs. A few that did not demonstrate spontaneous reversion were induced to revert by one or more of the alkylating mutagens.

\section{DISCUSSION}

This preliminary study of the nature of arginine auxotrophy has shown several interesting and perhaps important correlations between biosynthetic capability and habitat. Members of the novobiocin-resistant $S$. saprophyticus species group either do not require arginine or, when they do require this amino acid, can often revert to prototrophy and consequently grow on inorganic nitrogen sources. Staphylococcus sciuri does not require L-arginine for growth. The above species have a relatively wide host-range and are found primarily on the skin of mammals lower on the evolutionary scale than Great Apes and man (Kloos et al., 1976a, $b$; Kloos, unpublished results). They have also been isolated from soil and water frequented by mammals and birds and are generally believed to be capable of a rather free-living existence. Prototrophy makes this group of organisms particularly adaptable to environments containing low or perhaps no available organic nitrogen sources. A moderate to large percentage of the arginine auxotrophs produced have retained the ability to revert to arginine-independence or prototrophy. They are, in effect, not irreversibly dependent on the cutaneous environment for an exogenous source of L-arginine. This capability could serve as a homeostatic mechanism enabling the adaptation of these staphylococci to a variety of different and changing environments, containing various amounts of L-arginine, thereby ensuring the continued maintenance and proliferation of the species.

In contrast to the widely distributed species mentioned above, host-specific species or 
species with a relatively narrow host range usually required L-arginine and other amino acids for growth. One hypothesis is that host specificity in staphylococci may be, in part, a consequence of the accumulation of specific auxotypes, perhaps originating in isolated cutaneous populations. The advanced development of auxotypes with multiple requirements would tend to 'lock' a population into a niche, from which it could not easily be successfully established elsewhere. Certain auxotypes may have a competitive advantage over prototrophs due to the energy saved in reduced or incomplete biosynthesis of metabolites already in the cutaneous environment.

The failure of niche-specific or host-specific species, such as $S$. aureus, S. intermedius, $S$. simulans, S. warneri, $S$. capitis and Staphylococcus sp. 4, to revert to complete prototrophy is due not only to a lack of reversion from arginine auxotrophy to arginine-independence, but also to the presence of multiple amino acid and vitamin requirements. The lack of reversion from arginine auxotrophy alone appears to be due to the presence of deletions or multisite mutations in one or more arginine loci, as such powerful mutagens as NTG and EMS were unable to induce the production of arginine-independent revertants. Growth stimulation and enzyme studies suggest that the block(s) in L-arginine biosynthesis is before the sixth step in most strains. We believe that such stable fastidious species are highly specialized and perhaps not long ago were rather confined to their respective niches. The natural niche area for these species is generally small (e.g. the nares for $S$. aureus, head for $S$. capitis, or marsupium for Staphylococcus sp. 4) and rather isolated (Kloos et al., 1976 b). Especially in the case of $S$. aureus, man has intervened and expanded the range of possible habitats supporting growth, for example, by the manufacture and creation of new food products and perhaps by the microbial exchange afforded during the domestication of domestic animals.

It is particularly interesting that the human-specific species $S$. epidermidis and $S$. hominis have, in addition to multiple amino acid auxotrophy, a significant number of strains that are capable of reverting to arginine-independence. Such a capability may allow these species to occupy or colonize a wide range of niches in the human cutaneous ecosystem, which would include those not supplied with adequate levels of L-arginine for growth of auxotrophs. This might be one of the reasons why populations of these species extend over much of the cutaneous surface. Investigations into the availability of amino acids in various niches are required before the mechanisms involved in nutritional adaptation can be clearly elucidated.

The stimulation of growth of Staphylococcus strains by $N^{2}$-acetyl-L-ornithine indicates the presence of active acetylornithinase (EC 3.5.1.16) in these organisms rather than ornithine acetyltransferase, an enzyme used in the biosynthesis of L-arginine by Neurospora (Vogel \& Vogel, 1963b), Saccharomyces (De Deken, 1962) and Chlamydomonas (Dénes, 1970). Based on our preliminary results, the arginine biosynthetic pathway in Staphylococcus spp. appears to be similar to that of Salmonella typhimurium and Escherichia coli.

Our studies reported here with staphylococci paralleled independent studies on Neisseria gonorrhoeae (Ploscowe et al., 1977; Young et al., 1977) with regard to several aspects. These investigators found that the majority $(85 \%)$ of arginine auxotrophs in $N$. gonorrhoeae were capable of growing on L-ornithine, L-citrulline or L-arginine and were, therefore, suspected as being blocked early in the arginine biosynthetic pathway, like most Staphylococcus arginine auxotrophs. Based on recombination properties involving sequential transformational events, they concluded that multiple blocks are common in the arginine biosynthetic pathway of $N$. gonorrhoeae, a situation which we believe also occurs in the most specialized species of staphylococci.

This research was supported by Public Health Service research grant AI 08255 from the Institute of Allergy and Infectious Diseases, NIH, and Public Health Service research training grant 2 T01 GM00296. Paper No. 5579 of the Journal Series of the North Carolina Agricultural Experiment Station, Raleigh, North Carolina 27607, U.S.A. 


\section{REFERENCES}

CAtlin, B. W. (1976). Evolution of Neisseria gonorrhoeae. In Microbiology-1976, pp. 453-466. Edited by D. Schlessinger. Washington, D.C.: American Society for Microbiology.

De Deken, R. H. (1962). Pathway of arginine biosynthesis in yeast. Biochemical and Biophysical Research Communications 18, 788-795.

Demerec, M., Lahr, E. L., Balbinder, E., Miyake, T., Ishidsu, J., Mizobuchi, K. \& Mahler, B. (1960). Bacterial genetics. In Carnegie Institution of Washington Year Book, no. 59, pp. 426-441. Baltimore: The Lord Baltimore Press.

DÉNES, G. (1970). Ornithine acetyltransferase (Chlamydomonas reinhardti). Methods in Enzymology 17A, 273-277.

Emmetт, M. \& Kloos, W. E. (1975). Amino acid requirements of staphylococci isolated from human skin. Canadian Journal of Microbiology 21, 729-733.

Farrior, J. W. \& KLoos, W. E. (1976). Sulfur amino acid auxotrophy in Micrococcus species isolated from human skin. Canadian Journal of Microbiology 22, 1680-1690.

Hier, S. W., Cornbleet, T. \& Bergeim, O. (1946). The amino acids in human sweat. Journal of Biological Chemistry 166, 327-333.

Jones, M. E., SPector, L. \& LipMANN, F. (1955). Carbamyl phosphate, the carbamyl donor in enzymatic citrulline synthesis. Journal of the American Chemical Society 77, 819-820.

KLoos, W. E. \& Schleifer, K. H. (1975). Isolation and characterization of staphylococci from human skin. II. Descriptions of four new species: Staphylococcus warneri, Staphylococcus capitis, Staphylococcus hominis, and Staphylococcus simulans. International Journal of Systematic Bacteriology 25, 62-79.

Kloos, W. E., Schleifer, K. H. \& Smith, R. F. (1976a). Characterization of Staphylococcus sciuri sp. nov. and its subspecies. International Journal of Systematic Bacteriology 26, 22-37.

Kloos, W. E., Zimmerman, R. J. \& Smith, R. F. $(1976 b)$. Preliminary studies on the characterization and distribution of Staphylococcus and Micrococcus species on animal skin. Applied and Environmental Microbiology 31, 53-59.

Lowry, O. H. Rosebrough, N. J., Farr, A. L. \& Randall, R. J. (1951). Protein measurement with the Folin phenol reagent. Journal of Biological Chemistry 193, 265-275.

NAYLOR, H. B. \& Burgr, E. (1956). Observations on abortive infection of Micrococcus lysodeikticus with bacteriophage. Virology 2, 577-593.

Ploscowe, V., Short, H. \& Young, F. E. (1977). Analysis of the arginine pathway in naturally occurring auxotrophs of Neisseria gonorrhoeae. Abstracts of the Annual Meeting of the American Society for Microbiology 1977, 147.

Proctor, A. R. \& Kloos, W. E. (1973). Tryptophan biosynthetic enzymes of Staphylococcus aureus. Journal of Bacteriology 114, 169-177.

Prozesky, O. W. (1967). Arginine synthesis in Proteus mirabilis. Journal of General Microbiology 49, 325-334.

Rothman; S. \& Sullivan, M. B. (1949). Amino acids on the normal skin surface. Journal of Investigative Dermatology 13, 319-321.

SANDERSON, K. E. (1972). Linkage map of Salmonella typhimurium, Edition IV. Bacteriological Reviews 36, 608-637.

Schleifer, K. H. \& Kloos, W. E. (1975). Isolation and characterization of staphylococci from human skin. I. Amended descriptions of Staphylococcus epidermidis and Staphylococcus saprophyticus and descriptions of three new species: Staphylococcus cohnii, Staphylococcus haemolyticus, and Staphylococcus xylosus. International Journal of Systematic Bacteriology 25, 50-61.

Theil, E. C., Forsyth, G. W. \& Jones, E. E. (1969). Expression of the arginine regulation of Escherichia coli $\mathrm{W}$ : evidence for a second regulatory gene. Journal of Bacteriology 99, 267-273.

Vogel, H. J. \& BonNer, D. M. (1956). Acetylornithinase of Escherichia coli: partial purification and some properties. Journal of Biological Chemistry 218, 97-106.

Vogel, R. H. \& Vogel, H. J. (1963a). Acetylated intermediates of arginine synthesis in Bacillus subtilis. Biochimica et biophysica acta 69, 174176.

Vogel, R. H. \& VoGel, H. J. (1963b). Evidence for acetylated intermediates of arginine synthesis in Neurospora crassa. Genetics 48, 914.

VoGel, H. J. \& Vogel, R. H. (1974). Enzymes of arginine biosynthesis and their repressive control. Advances in Enzymology 40, 65-90.

Vogel, H. J., BACON, D. F. \& BAICH, A. (1963). Induction of acetylornithine $\delta$-transaminase during pathway-wide repression. In Informational Molecules, pp. 293-300. Edited by H. J. Vogel, V. Bryson \& J. O. Lamden. New York: Academic Press.

Young, F. E., Ploscowe, V. \& Short, H. (1977). The application of DNA-mediated transformation to elucidation of the pathobiology of Neisseria gonorrhoeae. In Modern Trends in Bacterial Transformation and Transfection, pp. 307-320. Edited by A. Portoles, R. Lopez \& M. Espinosa. Amsterdam: Elsevier/North-Holland Biomedical Press 